\title{
Field blood preservation and DNA extraction from wild mammals: methods and key factors for biodiversity studies
}

\section{Preservación en campo y extracción de ADN en sangre de mamíferos silvestres: métodos y factores claves para estudios de biodiversidad}

\author{
Juan D. Carvajal-Agudelo; M. Paula Trujillo-Betancur'; Daniela Velásquez-Guarín ${ }^{3}$; \\ Héctor E. Ramírez-Chaves ${ }^{4}$; Jorge E. Pérez-Cárdenas ${ }^{5}$; Fredy A. Rivera-Páez ${ }^{6}$
}

\begin{abstract}
'Biologist, M.Sc. student. Universidad de Caldas, Programa de Maestría en Ciencias Biológicas, Facultad de Ciencias Exactas y Naturales, Grupo de Investigación en Genética, Biodiversidad y Manejo de Ecosistemas, GEBIOME. Manizales - Caldas, Colombia; e-mail: jdavidcarvajal@gmail.com; (D) https://orcid.org/00000002-2888-7147

²Biologist student. Universidad de Caldas, Programa de Biología, Facultad de Ciencias Exactas y Naturales, Grupo de Investigación en Genética, Biodiversidad y Manejo de Ecosistemas, GEBIOME. Manizales - Caldas, Colombia; e-mail: mapatrub@gmail.com; (D) https://orcid.org/0000-0001-8035-5175

${ }^{3}$ Biologist, M.Sc. student. Universidad de Caldas, Facultad de Ciencias Exactas y Naturales y Centro de Museos, Museo de Historia Natural, Programa de Maestría en Ciencias Biológicas, Grupo de Investigación en Genética, Biodiversidad y Manejo de Ecosistemas, GEBIOME. Manizales - Caldas, Colombia; e-mail: daniela. bio202830@gmail.com; (D) https://orcid.org/0000-0002-6487-7608
\end{abstract}

${ }^{4}$ Biologist, M.Sc., Ph.D. Universidad de Caldas, Departamento de Ciencias Biológicas, Facultad de Ciencias Exactas y Naturales y Centro de Museos, Museo de Historia Natural, Grupo de Investigación en Genética, Biodiversidad y Manejo de Ecosistemas, GEBIOME. Manizales - Caldas, Colombia; e-mail: hector.ramirez@ ucaldas.edu.co; (D) https://orcid.org/0000-0002-2454-9482

${ }^{5}$ Bacteriologist, M.Sc. Universidad de Caldas, Departamento de Ciencias básicas para la Salud, Facultad de Ciencias para la Salud, Grupo de Investigación Biosalud. Manizales - Caldas, Colombia; e-mail: labmicro@ucaldas.edu.co; (D) https://orcid.org/0000-0002-7829-6505

${ }^{6}$ Lic. Biologist and Chemist, M.Sc., Ph.D. Universidad de Caldas, Departamento de Ciencias Biológicas, Facultad de Ciencias Exactas y Naturales, Grupo de Investigación en Genética, Biodiversidad y Manejo de Ecosistemas, GEBIOME. Manizales - Caldas, Colombia. e-mail: fredy.rivera@ucaldas.edu.co;

(i) https://orcid.org/0000-0001-8048-5818

How to cite: Carvajal-Agudelo, J.D.; Trujillo-Betancur, M.P.; Velásquez-Guarín, D.; Ramírez-Chaves, H.E.; Pérez-Cárdenas, J.E.; RiveraPáez, F.A. 2021. Field blood preservation and DNA extraction from wild mammals: methods and key factors for biodiversity studies. Rev. U.D.C.A Act. \& Div. Cient. 24(1):e1766. http://doi.org/10.31910/rudca.v24.n1.2021.1766

Open access article published by Revista U.D.C.A Actualidad \& Divulgación Científica, under Creative Commons License CC BY-NC 4.0

Official publication of the Universidad de Ciencias Aplicadas y Ambientales U.D.C.A, University, Accredited as a High-Quality Institution by the Colombian Ministry of Education

Received: November 17, $2020 \quad$ Accepted: April 19, $2021 \quad$ Edited by: Ingeborg Zenner de Polanía

\begin{abstract}
Studies on public health and wild mammal biodiversity include a genetic component. For blood samples, there must be optimal sample collection conditions since these can affect DNA preservation and
\end{abstract}

extraction. This study evaluated the use of liquid and dry DNA preservation methods and commercial and non-commercial DNA extraction methods on field-collected blood samples. For this, 264 total blood samples were collected from wild mammals. A first group of samples was preserved in guanidine hydrochloride $(\mathrm{GuHCl})$ and 
DNA was extracted using six commercial kits: Bioline, Norgen, Invitrogen, Promega, and Qiagen, in addition to phenol-chloroform isoamyl alcohol (PC) and guanidine thiocyanate (GIT). Another

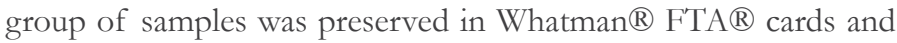
DNA was extracted with PC and GIT. The extractions with GIT and PC showed the highest values $(n g / \mu \mathrm{L})$ and variation in DNA concentration, while the commercial kit showed low variation. Sample preservation in Whatman ${ }^{\circledR}$ FTA $₫$ cards provided low variation and quantity of the extracted DNA compared with the use of $\mathrm{GuHCl}$. Concerning DNA quality, the commercial kits yielded higher purity, while GIT and PC-based protocols provided highly variable results. Furthermore, the use of GIT and PC yielded a higher amount of DNA, yet, of variable quality. Overall, extraction based on commercial kits and Whatman ${ }^{\circledR}$ FTA $₫$ preservation allowed obtaining more standardized DNA qualities and quantities.

Keywords: Biodiversity; DNA quality; Mammalia; Whole blood; Wildlife.

\section{RESUMEN}

Los estudios sobre salud pública y biodiversidad de mamíferos silvestres incluyen un componente genético. Para las muestras de sangre, se debe tener condiciones óptimas de colección, ya que pueden afectar la preservación y la extracción del ADN. Este estudio evaluó el uso de métodos de preservación de $\mathrm{ADN}$ líquido y seco y métodos de extracción de ADN comerciales y no comerciales, en muestras de sangre, recolectadas en campo. Para ello, se recogieron 264 muestras de sangre totales de mamíferos salvajes. Se preservó un primer grupo de muestras en clorhidrato de guanidina $(\mathrm{GuHCl})$ y se extrajo el ADN, utilizando seis kits comerciales: Bioline, Norgen, Invitrogen, Promega y Qiagen, además de dos protocolos no comerciales: fenol-cloroformo isoamil alcohol (PC) y guanidina tiocianato (GIT). Otro grupo de muestras, se preservó en tarjetas Whatman ${ }^{\circledR}$ FTA ${ }^{\circledR}$ y se extrajo el ADN, con PC y GIT. Las extracciones con GIT y PC mostraron los valores y variaciones más altas en la concentración de $\mathrm{ADN}(\mathrm{ng} / \mu \mathrm{L})$, mientras que el kit comercial mostró una baja variación. La preservación de la muestra en tarjetas Whatman ${ }^{\circledR}$ FTA $\AA$ proporcionó una baja variación y cantidad de ADN extraído, en comparación con el uso de $\mathrm{GuHCl}$. En cuanto a la calidad del ADN, los kits comerciales produjeron una mayor pureza (A260/280), mientras que los protocolos basados en GIT y PC proporcionaron resultados muy variables. Además, el uso de GIT y PC originó una mayor cantidad de ADN, pero de calidad variable. En general, la extracción basada en kits comerciales y la conservación Whatman ${ }^{\circledR}$ FTA ${ }^{\circledR}$ permitió obtener calidades y cantidades de ADN más estandarizadas.

Palabras clave: Biodiversidad; Calidad de ADN; Mammalia; Sangre total; Vida silvestre.

\section{INTRODUCTION}

Mammals (Mammalia) comprise a diverse group of vertebrates represented by more than 6550 species (Burgin et al. 2020). They are recognized by the ecological interactions with other vertebrates and invertebrates, the diversity of habits, behaviors, shapes, and by the roles in the trophic web (Nowak \& Walker, 1999; Nakagawa et al. 2007). Among these interactions, the role of mammals as vehicles of vectors and reservoirs of microorganisms is a key factor for understanding disease ecology (Williams \& Barker, 2008).

In recent years, the development of molecular analyses has favored the advancement of DNA applications such as the genetic characterization of wild mammals and their pathogens (Rodrigues et al. 2019), detection of disease-causing agents (Schijman et al. 2011), biodiversity studies, diagnostics, and biomedicine (Cho et al. 2007; Tang et al. 2016). For mammal studies, DNA samples have been extracted from fur, feces, blood, and several tissues (Henry \& Russello, 2011; Rey Fraile, 2013). For that reason, DNA extraction methods have been tested for different different preservation media (De Vries et al. 2009; Chakraborty et al. 2006; Gilbert et al. 2007; Hofreiter, 2012) and sample types including dry blood, environmental DNA (Ficetola et al. 2008), ancient DNA (Rohland \& Hofreiter, 2007), and fossilized material (Willerslev et al. 2004).

Diverse technical and biological factors play an important role in the use of DNA for diagnostic practice. DNA preservation and extraction methods largely determine the quantity and quality of DNA recovered from a sample (Psifidi et al. 2015). These methods must maintain the integrity of the genetic material from the moment of sample collection until DNA extraction and downstream applications (Tan \& Yiap, 2009; Demeke \& Jenkins, 2010). Furthermore, the amount of extracted DNA is influenced by the presence of DNA in red blood cells, which is markedly different among non-nucleated (mammals) and nucleated (e.g., birds, reptiles, amphibians, and fish) erythrocytes (Al-Shuhaib, 2017). High-quality nucleic acids extraction from field-fresh organic samples is complex and is associated with adverse factors that can promote DNA degradation, such as sample collection method, type of tissue, storage conditions and time (i.e., degree and time of degradation) (Camacho-Sanchez et al. 2013). These factors affect DNA amplification methods, which display variable levels of sensitivity and specificity (Schijman et al. 2011). The variations depend on technical factors such as sample volume, preservation conditions, DNA extraction method, PCR conditions (selected primers, reagents, and thermocycling conditions), as well as the number of circulating parasites in the blood sample (Mtambo et al. 2006; Salgado et al. 2007; Metwally et al. 2008; Asadzadeh et al. 2010). The selection of DNA extraction methods and sample preservation is essential to evaluate the viability of the sample and its use, according to its study objective. In general terms, it refers to higher DNA concentration and quality (Minamoto et al. 2016). Furthermore, aspects such as efficiency, cost-effectiveness, storage, and collection should also be considered to determine the viability of the sample and its use in methodologies that require DNA extraction (Chacon-Cortes \& Griffiths, 2014). Generally, high concentrations of ethanol (over 70\% ethanol) are used for tissue preservation (Ma et al. 2007), although other solutions such as RNA later $^{\text {TM }}$ Stabilization Solution (Thermo Fisher Scientific), guanidine hydrochloride ( $\mathrm{GuHCl})$, Longmire buffer, and NAP buffer are generically used to preserve diverse sample types (Camacho Sanchez 
et al. 2013; Mayta et al. 2019). Moreover, Whatman ${ }^{\circledR}$ FTA $®$ cards have proven useful to preserve DNA from blood (Sant'Anna et al. 2008; Dove et al. 2011; Choi et al. 2014; Rahikainen et al. 2016).

Due to the wide variety of sample preservation and DNA extraction methods, they should be assessed before their use, to guarantee successful DNA extraction.

Considering this we compared the quantity and quality of DNA recovered from blood samples of wild mammals using two field sample preservation and seven DNA extraction methods.

\section{MATERIALS AND METHODS}

Sample collection and sample site. Between March and October of 2019, wild mammals were captured at localities in the municipalities of Arauca $\left(07^{\circ} 05^{\prime} 25^{\prime \prime} \mathrm{N}, 70^{\circ} 45^{\prime} 42^{\prime \prime} \mathrm{W}\right)$ and Tame $\left(06^{\circ} 27^{\prime} 30^{\prime \prime} \mathrm{N}, 71^{\circ} 44^{\prime} 41^{\prime \prime} \mathrm{W}\right)$, in the Department of Arauca, Colombia. Mammals were captured using 60 Sherman traps and 10 Tomahawk traps. The specimens were collected under the permit granted by the Autoridad Nacional de Licencias Ambientales (ANLA) to the Universidad de Caldas (Resolution \# 02497, December 31, 2018) and the approval of the bioethics committee of the Faculty of Exact and Natural Sciences of Universidad de Caldas (June 2nd of 2017). Voucher specimens were deposited at the Natural History Museum of University of Caldas for taxonomic identification. The taxonomic identification of the small mammals was performed using taxonomic keys (Gardner, 2008; Patton et al. 2015; Díaz et al. 2016). Peripheral blood was collected through venipuncture with using $5 \mathrm{~mL}$-syringes or $25 \mathrm{G}$ needles with no coagulant for large and small mammals, respectively. All blood samples that yielded the minimum required amount were used to perform the extraction protocols. The samples were preserved using two methods: liquid and dry, using the same amount of blood $(250 \mu \mathrm{L})$. The liquid method consisted of one volume of blood with one volume of $5 \mathrm{M}$ guanidine hydrochloride (GuHCL); the samples were immediately stored at $4^{\circ} \mathrm{C}$ in a portable refrigerator. The dry method involved adding the blood evenly to an area of $2.5 \mathrm{~cm}^{2}$ on a Whatman ${ }^{\circledR}$ FTA $\AA$ card (GE Healthcare) and storing it at room temperature.

DNA extraction. DNA was extracted from the samples preserved in $\mathrm{GuHCl}$ using the following commercial kits: Isolate II Genomic DNA (Bioline $\left.{ }^{\circledR}\right)$, Genomic DNA Isolation Kit (Norgen $\left.{ }^{\circledR}\right)$, PureLink $^{\text {TM }}$ Genomic DNA Mini Kit (Invitrogen ${ }^{\circledR}$ ), Genomic DNA Purification Kit (Promega $\left.{ }^{\circledR}\right)$, and DNeasy Blood and Tissue Kit (Qiagen $\left.{ }^{\circledR}\right)$ (Table 1). All the extractions were done using the same amount of blood $(250 \mu \mathrm{L})$ and according to the manufacturers' protocols; however, some modifications were made for all the protocols in the lysis step, including the addition of $10 \mu \mathrm{L}$ of proteinase $\mathrm{K} 1 \mathrm{mg} / \mathrm{mL}$ prior to the extraction process and 2 additional hours of incubation time using the lysis buffer.

The non-commercial DNA extraction protocols used were phenolchloroform-isoamyl alcohol (25:24:1| v/v/v) (PC) (reagent from Thermo Fisher Scientific) and $4 \mathrm{M}$ guanidine thiocyanate (GIT) (reagent from Thermo Fisher Scientific) (Amaru et al. 2008). DNA extraction was done from the complete sampled area $\left(2 \mathrm{~cm}^{2}\right)$ of the Whatman ${ }^{\circledR}$ FTA cards using both protocols. Since these noncommercial protocols require separation of buffy coat, these were modified to use a greater volume of proteinase $\mathrm{K} 1 \mathrm{mg} / \mathrm{mL}$ (i.e., $30 \mu \mathrm{L}$ in total), a longer incubation time (6 hours), and two rounds of centrifugation for 30 minutes at 12000 RPM at room temperature. DNA was eluted using $50 \mu \mathrm{L}$ of elution buffer provided for each commercial kit and $50 \mu \mathrm{L}$ of $1 \mathrm{X}$ TE buffer $(10 \mathrm{mM}$ Tris, $1 \mathrm{mM}$ EDTA, pH 8.0) for non-commercial protocols.

DNA quality assessment and quantification. DNA quality was estimated using a Biochrom ${ }^{\mathrm{TM}}$ NanoVue Plus spectrophotometer; a $260 \mathrm{~nm} / 280 \mathrm{~nm}$ absorbance (Abs) ratio was used to assess the purity of the extracted DNA. The amount of DNA recovered by the different methods was determined on a Quantus Fluorometer ${ }^{\mathrm{TM}}$ (Promega ${ }^{\circledR}$ ) using the QuantiFluor ${ }^{\circledR}$ dsDNA System (Promega ${ }^{\circledR}$ ).

Statistical analysis. A Kruskal-Wallis test was performed to determine significant differences in DNA quality and quantity among the two sample groups: 1. Bioline, GIT, Invitrogen, Norgen, PC, Promega, and Qiagen DNA extraction methods; 2. GIT and PC with $\mathrm{GuHCl}$ and Whatman FTA sample preservation methods. Boxplots were graphed to interpret the variation in the data. The graphs and data were generated and analyzed respectively in $\mathrm{R}$ software v4.0.3.

\section{RESULTS AND DISCUSSION}

In total, 264 blood samples were collected from wild mammals, namely bats, marsupials, and rodents of the orders Chiroptera, Didelphimorphia, and Rodentia. The marsupials belonged to the species Didelphis marsupialis (5 blood samples). The bats included species of the families Noctilionidae (Noctilio albiventris: 2 samples), Phyllostomidae (genera Artibeus: 19; Carollia: 20; Phyllostomus: 6; Platyrrbinus: 12; Sturnira: 32; and Uroderma: 21), Molossidae (genera Molossus: 64; and Cynomops: 16), and Vespertilionidae (Myotis: 34). The rodents belonged to the families Cricetidae (Oecomys sp.: 15 samples), Echimyidae (Proechymis sp.: 5), Dasyproctidae (Dasyprocta fuliginosa: 1), Caviidae (Hydrochoerus hydrochaeris: 10), and an exotic species of Muridae (Rattus rattus: 2). None of the species or genera are listed in any national threatened category.

DNA quantification indicated that non-commercial protocols PC and GIT yielded the highest amounts of extracted DNA, yet these methods also showed the highest variation. The commercials kit, such as Promega, yielded the third highest concentration of DNA, while Norgen, Invitrogen, Qiagen, and Bioline showed similar DNA yields (Table 1). Regarding DNA quality, Abs 260/280 ratio $(\mathrm{nm} / \mathrm{nm})$ measurements indicated that GIT and the commercial kit by Norgen achieved the highest DNA qualities. Moreover, the commercial kits by Qiagen, Bioline, and Invitrogen, and the noncommercial protocol using PC showed similar and optimal results ranging from Abs 1.6 - 1.8 (considered as a pure DNA). Conversely, Promega showed quality scores below the required values (Figure 1, Table 1). The Shapiro-Wilks test showed that the data were not 
normal; consequently, a Kruskal-Wallis test was performed. The Kruskal-Wallis test revealed significant differences $(\mathrm{P}<0.01)$ in DNA quantity and quality among extraction methods.

The comparison between $\mathrm{GuHCl}$ and Whatman-FTA preservation methods using PC and GIT-based protocols showed that $\mathrm{GuHCl}$ promoted higher DNA concentrations but had higher variation (PC

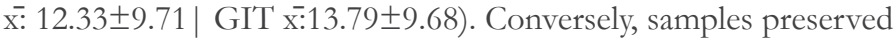
in Whatman ${ }^{\circledR}$ FTA $®$ cards yielded the lowest DNA concentrations

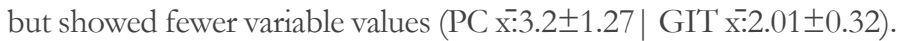
Regarding DNA quality, lower quality was obtained for DNA extracted with PC $\left(\mathrm{GuHCl} A 260 / 280\right.$ x: $1.31 \pm 0.21$ and Whatman ${ }^{\circledR}$

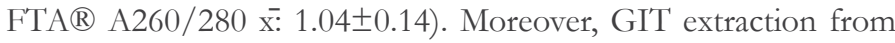
samples preserved in Whatman ${ }^{\circledR}$ FTA ${ }^{\circledR}(\bar{x}: 2.09 \pm 0.32)$ showed

Table 1. Measurements of concentration and quality of total DNA recovered using each extraction and preservation method.

\begin{tabular}{|c|c|c|c|c|c|c|c|c|c|c|}
\hline \multirow{2}{*}{$\begin{array}{l}\text { Preservation } \\
\text { method }\end{array}$} & \multirow{2}{*}{$\begin{array}{l}\text { Extraction } \\
\text { method }\end{array}$} & \multirow{2}{*}{$\mathbf{N}$} & \multicolumn{4}{|c|}{ DNA concentration $(\mathrm{ng} / \mu \mathrm{L})^{* *}$} & \multicolumn{4}{|c|}{ DNA quality (Abs $260 / 280$ ratio)** } \\
\hline & & & Mean & Median & Range & SD & Mean & Media & Range & SD \\
\hline GuHCl & Bioline & 24 & 3.28 & 2.96 & $2.23-4.78$ & 0.81 & 1.84 & 1.91 & $1.45-2.18$ & 0.24 \\
\hline $\mathrm{GuHCl}$ & Invitrogen & 18 & 2.36 & 2.01 & $1.66-4.34$ & 0.91 & 1.77 & 1.87 & $1.48-1.97$ & 0.22 \\
\hline $\mathrm{GuHCl}$ & Norgen & 12 & 3.35 & 2.72 & $2.55-5.4$ & 1.22 & 1.67 & 1.69 & $1.48-1.81$ & 0.13 \\
\hline $\mathrm{GuHCl}$ & Promega & 12 & 5.96 & 5.99 & $3.1-8.8$ & 2.85 & 1.46 & 1.47 & $1.4-1.54$ & 0.04 \\
\hline $\mathrm{GuHCl}$ & Qiagen & 39 & 4.37 & 4.2 & $3.18-7.6$ & 1.16 & 1.72 & 1.57 & $1.34-2.54$ & 0.33 \\
\hline $\mathrm{GuHCl}$ & PC & 87 & 12.33 & 8 & $1.95-29$ & 9.71 & 1.31 & 1.3 & $1.03-1.59$ & 0.21 \\
\hline $\mathrm{GuHCl}$ & GIT & 40 & 13.79 & 8.55 & $2.76-29$ & 9.68 & 1.69 & 1.61 & $1.19-2.3$ & 0.29 \\
\hline Whatman ${ }^{\circledR}$ FTA ${ }^{\circledR}$ & PC & 40 & 3.2 & 2.74 & $2.35-7.5$ & 1.27 & 1.04 & 0.98 & $0.82-1.30$ & 0.14 \\
\hline Whatman ${ }^{\circledR}$ FTA® & GIT & 40 & 3.64 & 3.02 & $2.26-9$ & 1.54 & 2.01 & 2.09 & $1.29-2.64$ & 0.32 \\
\hline
\end{tabular}

** Kruskal-Wallis test revealed significant differences $(\mathrm{P}<0.01)$ in DNA quantity and quality among extraction methods for GuHCl, and extraction methods, and for Whatman ${ }^{\circledR F T A}{ }^{\circledR}-\mathrm{GuHCl}$ and, PC -GIT.
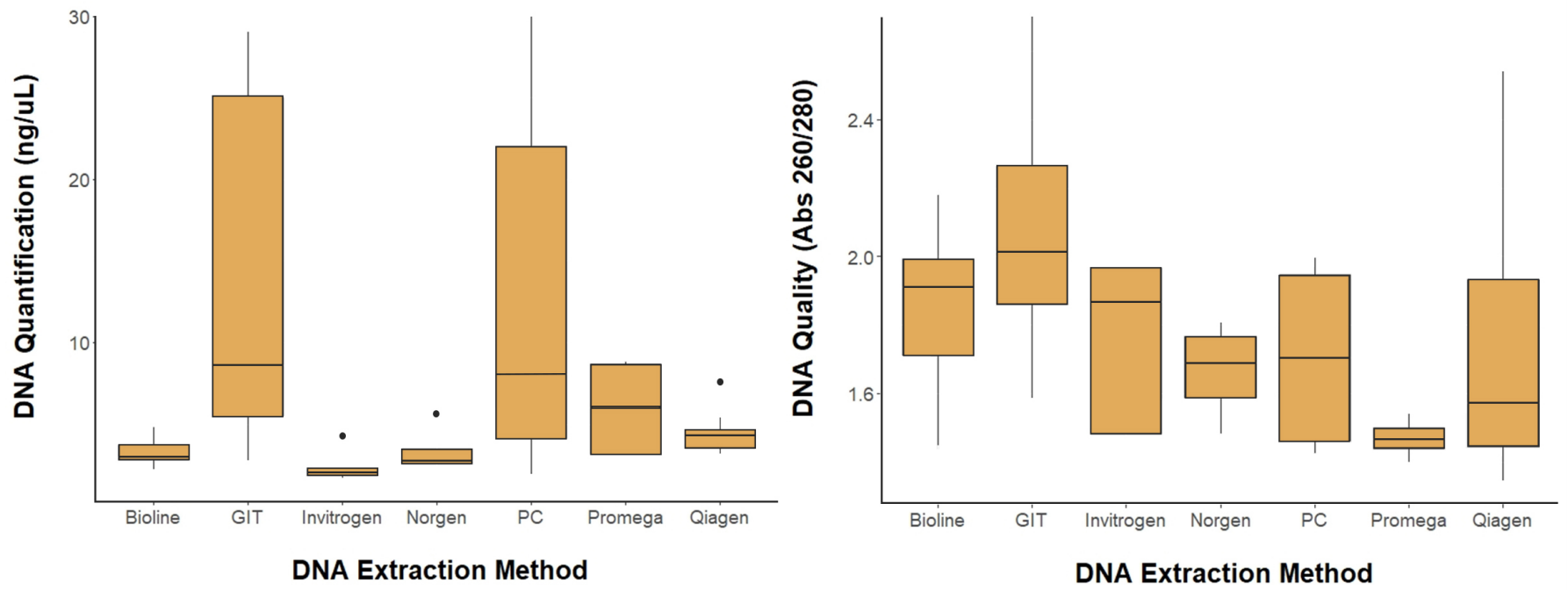

Figure 1. Boxplot of DNA quality measured at a ratio of absorbance 260/280 (nm/nm wavelength) (A) and DNA quantification (B) from DNA extracted using commercial kits and non-commercial protocols.

variation outside of the acceptable range of quality values compared with $\mathrm{GuHCl}(\overline{\mathrm{x}}: 1.69 \pm 0.29)$ (Figure 2, Table 1). The ShapiroWilks test showed that the data were not normal; consequently, a Kruskal-Wallis test was carried out. The Kruskal-Wallis test determined significant differences $(\mathrm{P}<0.01)$ in DNA quantity and quality between the two extraction methods using different sample preservation METHODS.

The non-commercial phase-based protocols (i.e., PC and GIT) showed the highest amount of extracted DNA, as well as the highest 


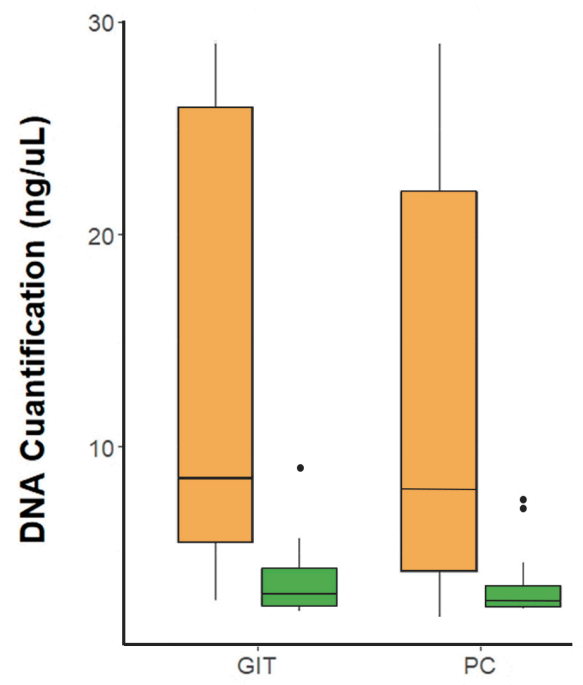

DNA Extraction Method

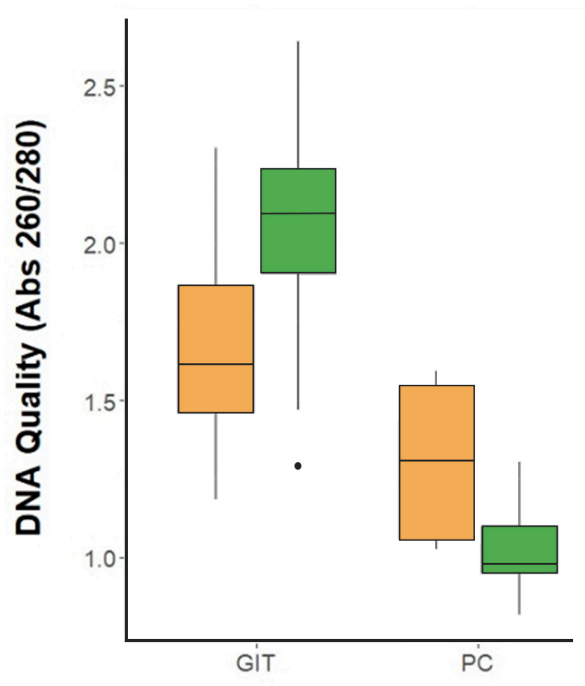

DNA Extraction Method

Conservation Method 追 $\mathrm{GuHCl}$ 追 Whatman FTA

Figure 2. Boxplot of DNA quality measured at a ratio of absorbance $260 / 280$ ( $\mathrm{nm} / \mathrm{nm}$ wavelength) (A) and DNA quantification (B) between DNA extracted using non-commercial protocols and preservation methods.

variation. The variability in DNA recovered from liquid samples, such as blood, during the manual recovery of the leukocyte layer (i.e., buffy coat) is due its contamination and variable concentration or volume; consequently, this method is affected by human manipulation (Desquesnes \& Tresse, 1996). These findings agree with variations reported in previous studies, as well as reports of higher total DNA yields and PCR confirmation (Albariño \& Romanowski, 1994; Malferrari et al. 2002; Kravchenko et al. 2006; Tang et al. 2006; Asadzadeh et al. 2010; Di Pietro et al. 2011; Karthikeyan et al. 2020). These non-commercial protocols might not be efficient because of the number of steps required for DNA extraction; however, they are inexpensive, easy to prepare, and accessible (Ibrahim et al. 2018).

In contrast, commercial column-based kits yield lower amounts of DNA with higher quality and lower variation. Given this low variability, these methods are used in automatization lines and, therefore, display greater efficiency regarding time, manipulation, and yield for standardized and continuous extraction of a large number of samples (Tan \& Yiap, 2009; Demeke \& Jenkins, 2010). Likewise, the low variation in DNA yield using Qiagen, Norgen, Invitrogen, and Bioline commercial methods is attributed the standardized methodology based on silica columns, which guarantee DNA integrity and are more effective (Esser et al. 2006). An exception to this is the Promega commercial kit, which does not use a silica column but instead standard phase separation that generates higher variation in total DNA quantity and lower quality.

Whatman ${ }^{\circledR}$ FTA $®$ cards provided the lowest DNA quantities for both extraction methods and highly variable quality values. The low yields could be attributed to sample fixation errors since the blood must be evenly distributed to allow all cells to be lysed. Furthermore, during this process, the card is impregnated with blood contaminants or adjacent samples (Borman et al. 2010). Nevertheless, Whatman ${ }^{\circledR}$
FTA ${ }^{\circledR}$ cards are widely used in research on blood parasites in birds and wild mammals and in field sample collection due to easy storage, rapid drying, and direct use in PCR (Dove et al. 2011; Choi et al. 2014; Rahikainen et al. 2016). This preservation method is useful for the collection of small volume samples such as those from birds and small mammals (e.g., bats and rodents).

The variable DNA concentration obtained from samples preserved in $\mathrm{GuHCl}$ may have been due to the use of liquid-based methodologies for both sample preservation and DNA extraction (e.g., PC and GIT). This liquid sample preservation method dilutes the blood in $\mathrm{GuHCl}$, which limits and reduces the concentration of blood used for DNA extraction. Moreover, sample collection for DNA extraction should be normalized using a vortex to avoid precipitations, which adds more steps to the DNA extraction protocol and reduces its efficiency (Ibrahim et al. 2018). The use of $\mathrm{GuHCl}$ could be indicated mainly for large sample volumes obtained from large mammals. On the other hand, there are some limitations provided by differences between organisms, species, and individuals that lead to variations in the number of nucleated cells (Hawkey, 2017) and the availability of DNA in the sample for extraction. Although these variations can hardly be avoided in the field, a more adequate comparison is recommended using livestock animals.

In conclusion, column-based methods allow optimizing quality, as well as automatizing the DNA extraction process. Similarly, non-commercial protocols enable higher DNA yields through rigorous steps. DNA preservation in the field will depend on the adverse conditions and precautions taken. Both $\mathrm{GuHCl}$ and Whatman-FTA cards can be used for the preservation of blood in the field. Furthermore, the choice of the commercial kit or non-commercial protocol for the DNA extractions is relevant and depends on factors such as the successful standardization of the amount of DNA required for adjacent processes, automated methods, and research costs. 
Acknowledgements: To the research group GEBIOME and Biosalud, the Natural History Museum of the University of Caldas and the "Vicerrectoria de Investigaciones y Postgrados", and the community of the surrounding areas of the municipalities of Tame and Arauca for their help and collaboration in the field activities. Conflicts of interest. The authors declare that there is no conflict of interest. Funding Statement. This study was funded by Minciencias through the project titled "The role of birds and small wild mammals in the circulation of ticks and rickettsiae in the Department of Arauca (Colombian Orinoquia)", code 112777758193 and contract No. 858 of 2017.

\section{REFERENCES}

1. AL-SHUHAIB, M.B.S.A. 2017. A universal, rapid, and inexpensive method for genomic DNA isolation from the whole blood of mammals and birds. J. Genetics. 96(1):171176. https://doi.org/10.1007/s12041-017-0750-6

2. AlBARIÑO, C.G.; ROMANOWSKI, V. 1994. Phenol extraction revisited: a rapid method for the isolation and preservation of human genomic DNA from whole blood. Molecular and Cellular Probes. 8(5):423-427. https: //doi.org/10.1006/mcpr.1994.1060

3. AMARU, R.; PEÑALOZA, R.; MIGUEZ, H.; TORRES, G.; CUEVAS, H. 2008. UMSAgen, método para la extracción simultánea de RNA y DNA para diagnóstico molecular. Cuadernos Hospital de Clínicas. 53:38-43.

4. ASADZADEH, N.; JAVANMARD, A.; NASSIRI, M. 2010. Comparison of rapid DNA extraction techniques for conventional PCR-RFLP analysis from mammalian whole blood. J.Mol. Genet. 2(3):32-35.

https://doi.org/10.3923/jmolgene.2010.32.35

5. BORMAN, A.M.; FRASER, M.; LINTON, C.J.; PALMER, M.D.; JOHNSON, E.M. 2010. An improved protocol for the preparation of total genomic DNA from isolates of yeast and mould using Whatman FTA filter papers. Mycopathologia. 169(6):445-449.

https://doi.org/10.1007/s11046-010-9284-7

6. BURGIN, C.J.; WILSON, D.E.; MITTERMEIER, R.A.; RYLANDS, A.B.; LACHER, T.; SECHREST, W. 2020. Illustrated checklist of mammals of the World. Lynx edicions (Spain).

7. CAMACHO SANCHEZ, M.; BURRACO, P.; GOMEZ MESTRE, I.; LEONARD, J.A. 2013. Preservation of RNA and DNA from mammal samples under field conditions. Molecular Ecology Resources. 13(4):663-673.

https:/ / doi.org/10.1111/1755-0998.12108
8. CHACON-CORTES, D.; GRIFFITHS, L.R. 2014. Methods for extracting genomic DNA from whole blood samples: current perspectives. J. Biorepository Science for Applied Medicine. 2:1-9.

https://doi.org/10.2147/BSAM.S46573

9. CHAKRABORTY, A.; SAKAI, M.; IWATSUKI, Y. 2006. Museum fish specimens and molecular taxonomy: a comparative study on DNA extraction protocols and preservation techniques. J. Applied Ichthyology. 22(2):160166.

http://doi.org/10.1111/j.1439-0426.2006.00718.x

10. CHO, Y.K.; LEE, J.G.; PARK, J.M.; LEE, B.S.; LEE, Y.; KO, C. 2007. One-step pathogen specific DNA extraction from whole blood on a centrifugal microfluidic device. Lab on a Chip. 7(5):565-573. https://doi.org/10.1039/b616115d

11. CHOI, E.H.; LEE, S.K.; IHM, C.; SOHN, Y.H. 2014. Rapid DNA extraction from dried blood spots on filter paper: potential applications in biobanking. Osong Public Health and Research Perspectives. 5(6):351-357. https://doi.org/10.1016/j.phrp.2014.09.005

12. DE VRIES, J.J.C.; CLAAS, E.C.J.; KROES, A.C.M.; VOSSEN, A.C.T.M. 2009. Evaluation of DNA extraction methods for dried blood spots in the diagnosis of congenital cytomegalovirus infection. J. Clinical Virology. 46:S37-S42. https://doi.org/10.1016/j.jcv.2009.09.001

13. DEMEKE, T.; JENKINS, G.R. 2010. Influence of DNA extraction methods, PCR inhibitors and quantification methods on real-time PCR assay of biotechnology-derived traits. Analytical and Bioanalytical Chemistry. 396(6):19771990.

https://doi.org/10.1007/s00216-009-3150-9

14. DESQUESNES, M.; TRESSE, L. 1996. Evaluation of sensitivity of PCR for detecting DNA of Trypanosoma vivax with several methods of blood sample preparations. Revue d'elevage et de Medecine Veterinaire Des Pays Tropicaux. 49(4):322-327.

15. DI PIETRO, F.; ORTENZI, F; TILIO, M.; CONCETTI, F.; NAPOLIONI, V. 2011. Genomic DNA extraction from whole blood stored from 15-to 30-years at $20 \mathrm{C}$ by rapid phenol-chloroform protocol: A useful tool for genetic epidemiology studies. Molecular and Cellular Probes. 25(1):44-48.

https://doi.org/10.1016/j.mcp.2010.10.003

16. DÍAZ, M.M.; SOLARI, S.; AGUIRRE, L.F.; AGUIAR, L.M.; BARQUEZ, R.M. 2016. Clave de Identificación de los Murciélagos de Sudamérica - Chave de Identificação dos 
Morcegos da América do Sul. Programa de Conservación de los Murciélagos de Argentina. Publicación Especial PCMA Nro 2. Editorial Magna Publicaciones, 160p.

17. DOVE, C.J.; DAHLAN, N.F.; HEACKER, M.A.; WHATTON, J.F. 2011. Using Whatman FTA $®$ cards to collect DNA for bird-strike identifications. Human-Wildlife Interactions. 5(2):218-223. https://doi.org/10.26077/csen-dy04

18. ESSER, K.H.; MARX, W.H.; LISOWSKY, T. 2006. MaxXbond: first regeneration system for DNA binding silica matrices. Nature Methods. 3(1):68. https://doi.org/10.1038/nmeth845

19. FICETOLA, G.F.; MIAUD, C.; POMPANON, F.; TABERLET, P. 2008. Species detection using environmental DNA from water samples. Biology Letters. 4(4):423-425. https://doi.org/10.1098/rsbl.2008.0118

20. GARDNER, A.L. 2008. Mammals of South America, volume 1: marsupials, xenarthrans, shrews, and bats (Vol. 2). University of Chicago Press (United States).

21. GILBERT, M.T.P.; MOORE, W.; MELCHIOR, L.; WOROBEY, M. 2007. DNA extraction from dry museum beetles without conferring external morphological damage. PloS One. 2(3):e272.

https://doi.org/10.1371/journal.pone.0000272

22. HAWKEY, C.M. 2017. Comparative mammalian haematology: cellular components and blood coagulation of captive wild animals. William Heinemann Medical Books. London, UK. 310p.

https://doi.org/10.1016/C2013-0-06344-X

23. HENRY, P.; RUSSELLO, M.A. 2011. Obtaining high-quality DNA from elusive small mammals using low-tech hair snares. European J. Wildlife Research. 57(3):429-435. https://doi.org/10.1007/s10344-010-0449-y

24. HOFREITER, M. 2012. Nondestructive DNA extraction from museum specimens. Ancient DNA Springer. p.93-100. https://doi.org/10.1007/978-1-61779-516-9_13

25. IBRAHIM, N.A.; NASSAR, S.A.; ABD EL-GAWAD, A.M.; OMAR, M.F. 2018. Comparing the efficiency in DNA extraction between organic phenol and magnetic beads methods. Forensic Med. Toxicol. 16:10-17. https://doi.org/10.21608/zjfm.2018.2419.1007

26. KARTHIKEYAN, K.; SARANYA, R.; BHARATH, R.; VIDYA, R.; ITAMI, T.; SUDHAKARAN, R. 2020. A simple filter paper-based method for transporting and storing Enterocytozoon hepatopenaei DNA from infected
Litopenaeus vannamei tissues. J. Invertebrate Pathology. 169:107305.

https://doi.org/10.1016/j.jip.2019.107305

27. KRAVCHENKO, A.V.; CHETVERINA, E.V.; CHETVERIN, A.B. 2006. Preservation of nucleic acid integrity in guanidine thiocyanate lysates of whole blood. Russian J. Bioorganic Chemistry. 32(6):547-551.

https://doi.org/10.1134/S1068162006060070

28. MA, D.; ZHUO, X.Y.; BU, J.; XIANG, P.; SHEN, B.H. 2007. Research of on the stability of ethanol in preservation of ethanol in blood. Fa Yi Xue Za Zhi. 23(2):117-119.

29. MALFERRARI, G.; MONFERINI, E.; DEBLASIO, P.; DIAFERIA, G.; SALTINI, G.; DEL VECCHIO, E.; ROSSI-BERNARDI, L.; BIUNNO, I. 2002. High-quality genomic DNA from human whole blood and mononuclear cells. Biotechniques. 33(6):1228-1230. https://doi.org/10.2144/02336bm09

30. MAYTA, H.; ROMERO, Y.K.; PANDO, A.; VERASTEGUI, M.; TINAJEROS, F.; BOZO, R.; HENDERSON-FROST, J.; COLANZI, R.; FLORES, J.; LERNER, R. 2019. Improved DNA extraction technique from clot for the diagnosis of Chagas disease. PLoS Neglected Tropical Diseases. 13(1):e0007024. https://doi.org/10.1371/journal.pntd.0007024

31. METWALly, L.; FAIRLEY, D.J.; COYLE, P.V.; HAY, R.J.; HEDDERWICK, S.; MCCLOSKEY, B.; O’NEILL, H.J.; WEBB, C.H.; ELBAZ, W.; MCMULLAN, R. 2008. Improving molecular detection of Candida DNA in whole blood: comparison of seven fungal DNA extraction protocols using real-time PCR. J. Medical Microbiology. 57(3):296-303.

https://doi.org/10.1099/jmm.0.47617-0

32. MINAMOTO, T.; NAKA, T.; MOJI, K.; MARUYAMA, A. 2016. Techniques for the practical collection of environmental DNA: filter selection, preservation, and extraction. Limnology. 17(1):23-32. https://doi.org/10.1007/s10201-015-0457-4

33. MTAMBO, J.; VAN BORTEL, W.; MADDER, M.; ROELANTS, P.; BACKELJAU, T. 2006. Comparison of preservation methods of Rhipicephalus appendiculatus (Acari: Ixodidae) for reliable DNA amplification by PCR. Experimental \& Applied Acarology. 38(2-3):189-199. https://doi.org/10.1007/s10493-006-0004-4

34. NAKAGAWA, M.; HYODO, F.; NAKASHIZUKA, T. 2007. Effect of forest use on trophic levels of small mammals: an analysis using stable isotopes. Canadian J. Zoology. 85(4):472-478.

https://doi.org/10.1139/Z07-026 
35. NOWAK, R.M.; WALKER, E.P. 1999. Walker's Mammals of the World (Vol. 1). JHU press (United States).

36. PATTOON, J.L.; PARDIÑAS, U.F.J.; D'ELÍA, G. 2015. Mammals of South America, volume 2: rodents (Vol. 2). University of Chicago Press (United States).

37. PSIFIDI, A.; DOVAS, C.I.; BRAMIS, G.; LAZOU, T.; RUSSEL, C.L.; ARSENOS, G.; BANOS, G. 2015. Comparison of eleven methods for genomic DNA extraction suitable for large-scale whole-genome genotyping and long-term DNA banking using blood samples. PloS One. 10(1). https://doi.org/10.1371/journal.pone.0115960

38. RAHIKAINEN, A.L.; PALO, J.U.; DE LEEUW, W.; BUDOWLE, B.; SAJANTILA, A. 2016. DNA quality and quantity from up to 16 years old post-mortem blood stored on FTA cards. Forensic Science Internal. 261:148-153. https://doi.org/10.1016/j.forsciint.2016.02.014

39. REY FRAILE, I.R. 2013. Museos, colecciones científicas y ADN. Memorias de La Real Sociedad Española de Historia Natural. 11:53-68.

40. RODRIGUES, M.S.; LIMA, L.; DAS CHAGAS XAVIER, S.C.; HERRERA, H.M.; ROCHA, F.L.; ROQUE, A.L.R.; TEIXEIRA, M.M.G.; JANSEN, A.M. 2019. Uncovering Trypanosoma spp. diversity of wild mammals by the use of DNA from blood clots. International Journal for Parasitology: Parasites and Wildlife. 8:171-181. https://doi.org/10.1016/j.ijppaw.2019.02.004

41. ROHLAND, N.; HOFREITER, M. 2007. Comparison and optimization of ancient DNA extraction. Biotechniques. 42(3):343-352.

https://doi.org/10.2144/000112383

42. SALGADO, A.; VIEIRALVES, T.; LAMARÃO, F.R.M.; ASSUMPÇÃO, L.L.M.; GOMES, D.; JASCONE, L.; VALADÃO, A.L.; ALBANO, R.M.; LÔBO-HAJDU, G. 2007. Field preservation and optimization of a DNA extraction method for Porifera. In: Custódio, M.R.; LôboHajdu, G.; Hajdu, E.; Muricy, G. (eds). Porifera Research.
Biodiversity, Innovation and Sustainability. Livros de Museu Nacional 28, Rio de Janeiro. Porifera Research: Biodiversity, Innovation and Sustainability. p.555-560.

43. SANT'ANNA, M.R.V.; JONES, N.G.; HINDLEY, J.A.; MENDES-SOUSA, A.F.; DILLON, R.J.; CAVALCANTE, R.R.; ALEXANDER, B.; BATES, P.A. 2008. Blood meal identification and parasite detection in laboratory-fed and field-captured Lutromyia longipalpis by PCR using FTA databasing paper. Acta Tropica. 107(3):230-237. https://doi.org/10.1016/j.actatropica.2008.06.003

44. SCHIJMAN, A.G.; BISIO, M.; ORELLANA, L.; SUED, M.; DUFFY, T.; JARAMILLO, A.M.M.; CURA, C.; AUTER, F.; VERON, V.; QVARNSTROM, Y. 2011. International study to evaluate PCR methods for detection of Trypanosoma cruzi DNA in blood samples from Chagas disease patients. PLoS Neglected Tropical Diseases. 5(1). https://doi.org/10.1371/journal.pntd.0000931

45. TAN, S.C.; YIAP, B.C. 2009. DNA, RNA, and protein extraction: the past and the present. BioMed Research International. https://doi.org/10.1155/2013/628968

46. TANG, S.; ZHANG, H.; LEE, H.K. 2016. Advances in sample extraction. Analytical Chemistry. 88(1):228-249. https://doi.org/10.1021/acs.analchem.5b04040

47. TANG, X.W.; LIAO, C.; LI, Y.; XIE, X.M.; HUANG, Y.L. 2006. Modified guanidine hydrochloride method for DNA extraction from cord blood used in HLA genotyping. Zhongguo Shi Yan Xue Ye Xue Za Zhi. 14(2):363-365.

48. WILlERSLEV, E.; HANSEN, A.J.; POINAR, H.N. 2004. Isolation of nucleic acids and cultures from fossil ice and permafrost. Trends in Ecology \& Evolution. 19(3):141-147. https://doi.org/10.1016/j.tree.2003.11.010

49. WILLIAMS, E.S.; BARKER, I.K. 2008. Infectious diseases of wild mammals. John Wiley \& Sons (Iowa, United States). 560p.

https://doi.org/10.1002/9780470344880 